\title{
Turkish Manuscripts Important Historical Source On The History Of The Relationship Between The Central Asian Khanets And The Ottoman Empire
}

\author{
Zumrad Rakhmonkulova \\ Head Of The Department "Source Science And Archival Studies" Faculty Of The History Of \\ The National University Of Uzbekistan
}

Journal Website: http://usajournalshub.c om/index,php/tajssei

\section{ABSTRACT}

This article analyzes information on the history of the relationship between the Central Asian Khanets and the Ottoman empire by Turkish manuscripts. The paper also analyzes the history of caravan routes and trade relations between the two countries, written by medieval historians such as $\mathrm{H}$. Vamberi, Miyona Buzruk, Abdurazzak Samarkandi, Seydi Ali Rais, Mehmet Emin Efendi.

\section{KEYWORDS}

Great Silk Road, diplomatic relations, trade and economic relations, Bukhara, Europe, Central Asian khanates, Ottoman Empire, Iran, Sultan Suleiman, Shaybanids, Ashtarkhanids, caravan routes

\section{INTRODUCTION}

The history of diplomatic, trade and cultural relations between the states of Central Asia and the Ottoman Empire has a long history. In turn, the caravan routes played an important role in trade relations between Central Asia and foreign countries. The caravan played an important role in the trade relations of the ancient cities of Central Asia with India, China and Byzantium through roads. These caravan routes connected Central Asia with European countries. Information about this was provided by many valuable sources, travel notes, research. In particular, in the studies of Bekmuradov, Kh, Gasratyan M.,Oreshkova, 
Borns A., Goloborodko I. , Gulamov, and H. Hakimkhan, such issues as the history of Tashkent, trade and cultural relations, social political life, education of the population [1].

The works of medieval Arab geographers provide information about the major markets of Tashkent. Zarafshan was of great importance as a city connecting the Fergana Valley with Dashti Kipchak, Eastern Europe and China. From the 16th century, Tashkent became famous for its dried fruits, iron and copper products, handicrafts, ready-made clothes, weapons, and saddles. Livestock and leather products were brought to Tashkent. Tashkent has long established trade relations with the people of Siberia. Various animal skins and furs were brought to Tashkent from Siberia. In the 19th century, gold and silver embroidered cloth, satin, adras and their products, korakul leather, and carpets made in Bukhara and Khiva could be found in the markets of Iran and China.

\section{RESEARCH METHOLOGY}

This study analyzes the history of diplomatic, trade, economic and cultural relations between the Central Asian khanates and the Ottoman Empire from a number of Turkish historical sources. In the course of the research, historical sources belonging to different periods were analyzed on the basis of the periodic research method.

However, it should be noted that historical information on the history of diplomatic relations between the Central Asian khanates and the Ottoman Empire can be found not only in Turkish sources, but also in Arabic and Persian, as well as in the National Archives of Uzbekistan. However, the research method of archival source studies also plays an important role in the analysis of these documents from the point of view of source studies. Today, a lot of research is being conducted in Uzbekistan on archival sources. For example, M. Joniev, Sh. Davurova in arabic, persian, turkish [2], Kh. Burieva, Sh.Choriev, A.Nazarov, Z.Rahmonkulova [3] analyzed the archival documents of the Turkestan period from the point of view of source studies.

\section{THE MAIN FINDINGS AND RESULTS}

The Silk Road has, from time immemorial, connected East and West. Industrial goods produced in Europe, Chinese tea, Indian sugar and Iranian, Turkish and Indian merchants were found in Bukhara [4]. Yarn and silk, atlas (uzbek naional fabric), clothing made of these materials in Bukhara and Khiva, Karakul leather and Turkmen horses were sent to China and through Iranian territory to the Ottoman state. The Central Asian Khanates were linked to Osman and Iran through the towns of Merv and Mashhad or across the Khiva-Mashhad road along the Caspian Sea. Mashhad was the caravan center of the Persian Gulf and Trebizond. Two roads from Northern Iran led to Mashhad: Astrabad-Shahroud-NishapurMashhad (south track) and Astrabad-BujnardKuchan-Gunabad-Mashhad (north track) [5].

As a result of the incessant wars between the Central Asian Khanate and Iran and the internecine wars within the Khanate, the importance of the Mashhad-Merv route gradually declined. According to A.Wamberi, although the length of the direct route from Mashhad to Bukhara was 10 days, the caravans had to follow another road (Herat-MaymanaAnhai), which was three times longer. There were also frequent attacks by highwaymans along the way [6].

Due to the intensification of the Shia-Sunni rivalry along the Mashhad-Merv route, Central 
Asian pilgrims in most cases preferred to reach Mecca by a longer but safe route through the Orenburg-Astrakhan-Ottoman state. This route played an important role in the mutual relations between Central Asia and the Ottomans.

In the 16th and mid-18th centuries, cultural ties were established between the states of the Sheibanids, Ashtarkhanids and Ottomans. In 1927, an article entitled "Four Important Books on Uzbek History" by Miyon Bouzruk of Uzbek intellectuals (1892-1937) was published in the pages of the magazine "Education and Teacher". The paper gives information about the work of Fazdullah ibn Ruzbehan Isfaghaniy (1457-1529) "Mehmananamai Bukhara". The author of this work during the reign of the Iranian Shah, Ismail Safavi, came to Central Asia to Sheibaniyhan due to persecution and left historical notes describing his military activities. Fazlullah ibn Ruzbehan Isfaghaniy marched against Ismail Safavi and called on Sultan Selim I of Osman to join the war against the Iranian Shah. For this reason, it is possible that the Herat copy of his work Fazlullah ibn Ruzbehan Isfaganiy could have given to Selim I or Suleiman I. Miyon Bouzruk about his new found book told to the Russian turkologist A.N.Samoilovich in Istanbul, Having heard about this from Samoilovich V.V.Bartold in 1929 during his stay in Turkey to give lectures at the invitation of the Istanbul University, he copied copies of "Mehmanai Bukhara" [7].

Miyon Busruk even cites poetry written in Uzbek by Sheibaniyhan. In the library of Nuri Osmania there is another book found by Mien Busruk. It is a work by Sharafiddin Ali Yazdiya "Zafarname", translated into Uzbek and still stored there. This translation was made by Muhammad Ali ibn Darves Ali Al-Bukhari in 1519. Miyon Bouzruk briefly introduces this work by translating it into Uzbek.
Data of Miyong Buzruk attests to the Ottoman intelegents and people's interest in Central Asian history and culture.

The collection of manuscripts of the Institute contains the works of Jalaliddin Rumi (12071273), Mustafa Çelebi (1608-1657). The stored copy of the work of Mustafa Çelebi "Takvim uttavorikh" was copied in 1678 . As well as copies of the works dedicated to Suleiman I, translated into Turkish by Yusuf ibn Abdullatif "Sukhbat ul-ahbor", are also kept.

To the present day valuable sources in the form of "Sayokhanthame» about economic relations between states through caravan routes have been preserved. In particular, the work of Abdurazzak Samarkandiy "Matlaus sadayn wa majmaul bahryain", Seidi Ali Rais "Mirotul mamolik" («Mirror of countries»). These works provide valuable information on the political situation, diplomatic relations, trade and economic relations of the Ottomans, India, Central Asia and Iran.

Seidi Ali Rais is a Turkish author who lived and worked in the 16th century. He became famous in Central Asia under the pseudonym "Kotibi Rumiy". His peru belongs to the geographical work "Muhit". He also translated the works of Ali Kushchi into Turkish and popularized it.

Seidi Ali Rais participated in the hostilities of Sultan Suleiman Konuni (1520-1566) against Iran in 1548, and in the Battle of Cyprus in 1552. For his military service in these battles, he received the boundless respect of Sultan Sultan Suleiman and was later appointed Sultan of Aleppo. He was later appointed as a military Commander of Egypt and sent to fight against the Portuguese fleet in the Suez Canal. But in the battle, the Turkish fleet was defeated and the remaining ships 
sailed for northern India. Seidi Ali Rais visited India and met Zahiriddin Muhammad Babur's son, Humayun Mirzo. Seidi Ali Rais travels through Sindh, Punjab, Afghanistan, Central Asia, Khorasan, Azerbaijan and Iran four years later. In 1556 he wrote the work "Mirotul Mamolik" [8].

Seidi Ali Rais gives valuable information about the routes through Kunduz, Kubadien, Termez, Turkestan, Iran, Shirvan has a large role in trade and economic relations of Central Asia and Ottoman Turkey.

In 1555, Saydi Ali Rais apparently arrived in Samarkand via Sangardak and Shahrisabz. He met with Nawruz Ahmedkhan (Barakhan) and presented presents.

Seidi Ali Rais makes a pilgrimage to the tombs of Abu Mansur Moturidiya, Shahi Zind and Khoja Akhrar. Having passed through Zarafshan, he visited Gijduvan and the tomb of Abduholik Gijduwani. He then goes to Bukhara. Having visited Bukhara for fifteen days, he visits the holy sites and tombs of Bahou-uddin Nakshdandi, Chorbakar, Said Mirkutol, Ismail Samani, Hazrati Ayyub, and Khorezm Pahlavan Mahmud, Najmiddin Kubro, Zamakhari.

Saydi Ali Rais's work "Mirotul Mamolik" is an important source on the history of Central Asia of the 16th century, providing information on politics, economics, geography, ethnography, as well as information on caravan routes and diplomatic relations.

In the collection of manuscripts of Istanbul University you can find some productions covering the history of the Ottomans. One such work is "Hasht Bihisht" by Hakimuddin Idris ibn Hismuddin Ali al-Bidlij (Tashkent copy refers to the 17th century).
The peoples of Central Asia were also interested in written Turkish literature. Manuscripts written in Arabic, Persian and Turkish in the Ottoman State are kept in the collection of manuscripts of the Abu Raihan Berouni Institute of Oriental Studies of the Academy of Sciences of Uzbekistan.

The centre of trade for Central Asian merchants, where they could conduct trade relations by European merchants, was the main commercial port of the Caspian Sea of Baku. According to Evliya Çelebi, a Turkish traveller who lived in the 16th century, Baku was the commercial port of the Shirvan region.

By the 16th century, with the increasing role of the Caspian Sea in Europe-Asia's trade relations, large trading points formed on its west bank, occupying an important place in the trade of Russia, Western Europe, Central Asia, China and India.

In the 17th and early 18th centuries, competition between France, France and the Netherlands intensified in order to capture the lead in supplying the Turkish market. For the sale of goods produced at the manufactures of Western Europe and the Levant markets, Venetians supplied silk and other fabrics, glass and paper, Dutch cloth and metal products, English clothing, copper, watches, leather and steel. In the Ottoman State, the role of transit trade was much greater than in other countries. The government passed laws regulating caravan trade, caravanserai activities, traders. During this period, Mashhad served as a collection point for goods in transit trade from Trebizond and the Persian Gulf to Asia.

At the beginning of the 19th century, the British traded with Iran at the crossroads of the main trade routes from which goods from the East 
were exported to Europe via two roads: Trebizond, Tabriz and Transcaucasia. Using these two roads, the British were able to establish themselves in Iran and to survive Russian goods from the local market. Between 1830 and 1844, hegemony in Iran's markets shifted from Russia to England.

In Samarkand, a special kind of bahmal was made, which was supplied to Europe, and from this fabric wore the clothes of the upper class of Central Asia on festive and solemn days. Due to the increasing demand for this material, workshops for the manufacture of this fabric have been established in Europe. One such workshop was located in the city of BurganBress in the Department of Ain-France. The name of the cloth confirms that the priest Savva, who lived in the 17th century, was from Bukhara. Also, in some sources, the name was related to the city of Bursa, where silk was produced in the Aucmann state.

An important historical source in the study of links between the Central Asian Khanate and the Ottoman State is the work of Mehmed Amin Efendi "Istanbuldan Orta Asyaga Siyakhat" («The journey from Istanbul to Central Asia») [9].

Mehmed Amin Efendi left Istanbul in 1878 to travel to Central Asia. His work reflects his impressions of traveling to Central Asia, as well as information about the mutual relations between the Khanate of Central Asia and the Ottoman State.

It should be emphasized that the permanent missions of the Khanates of Central Asia to the Ottoman State at the end of the 18th and midnineteenth centuries did not exist, therefore there is no consistency in the relations of these States. In the tradition of Central Asian ambassadorial relations, a local ambassador was attached to the ambassador from the
Ottoman State, who accompanied him back [10]. If the ambassador returned alone, the relationship was suspended indefinitely or until such a relationship became necessary. The ambassador had to learn and study the existing political order and the state situation, deliver skilfully written letters and gifts. It was also envisaged not to exacerbate the relationship because of the Ambassador's activities. According to the plan, the ambassador going from Central Asia to Istanbul was to be at the reception of the Iranian Shah, to inform him of his powers and to provide him with information on the relations between the Central Asian states and the Ottoman State [11]. In the letters of the rulers of the Central Asian States, the ambassador's purpose was not fully described, and usually the letter ended with the phrase "Hear the rest from the ambassador". This, first, protected bilateral relations from interference by a third and often enemy party, and second, spoke of the high status of the Ambassador and his powers. Information on diplomatic relations and embassy ties shows that the Khiva Khans wrote in Uzbek in correspondence with the Ottoman sultans, while the Emir of Bukhara and the Kokand khan wrote in Persian. The letters of the Central Asian rulers correspond to the diplomatic traditions of that era and were written with special Eastern respect. The letters of the Central Asian rulers to the Ottoman Sultans reveal the fact that at the end of the 18th and mid-nineteenth centuries diplomatic, cultural and trade and economic relations between the two sides existed. The letters assert that, with regard to the security of trade routes and the development of diplomatic relations, cooperation must continue to be strengthened, ambassadors must continue to be exchanged and ways must be found to rid caravan roads of bandits. These messages are considered important sources in the study of the history of ambassadorial ties 
of the Central Asian states. Their comparative study with archival data is important in order to rid the history of embassy connections of inaccuracies.

\section{CONCLUSION}

In conclusion, it should be said that the Turkish manuscripts sources play a very important role in the study of the history of the relationship between the Central Asian Khanate and the Ottoman Empire. According to the analysis of Turkish historical sources, the Caravan routes played a large role in the political, economic and cultural ties of Central Asia with neighboring states. With the help of caravan routes from the ancient epochs of India and China through Central Asia to Byzantium and Rome, turmeric, Nile paint, ivory, diamonds, emeralds, silk, bronze and porcelain were delivered.

\section{REFERENCES}

1. Bekmuradov, Kh, 1996. Relation of between Turkistan and Rome, Amir Temur and his role on the world history, Tashkent: Fan, p.72; Gasratyan M.,Oreshkova S.1975. Essays on Turkey's history.Moskow.:Science; a. Shabanov F. 1967. State and law system of Turkey in the period of Tanzimat.Baku.; Borns A. 1848. Puteshestviye iz Indii v Kabul, Tatariyu I Persiyu, T.II, Moskva: Pp. 389-397; Goloborodko I. 1908. Old and new Turkey. -Moskow. [6] Goloborodka , 1908 Staraya I Novaya Tursiya: Moskva: p.193.; Gulamov, H. 2005. Diplomaticheskiye otnoseniye gosudarsv Sredney Azii s Rosiey $v$ XVIII-pervoy polovine- XIX veka, Tashkent: Fan, Pp.216-217; Hakimkhan M. 1966. Memories/ Editors
Tashkent.:Science.; The same author. 1988. «Muntahab at Tashkent avarih»(translation from Persian by $\mathrm{E}$. Hurshut) // Materials on the history of Central Asia in the 10th and 19th centuries. - Tashkent.: Science. -P.276295

2. Joniev M. The policy of the Russian Empire on the issue of pilgrimage of Turkestan Muslims. I Problems of integration of history and archiving in the media field. Ilm-ziyo-zakovat. 2019. 118-124; Dovurova Sh. Coverage of trade relations in the Emirate of Bukhara in archival documents. / Problems of integration of history and archiving in the media field. Ilm-ziyozakovat, 2019. 118-124

3. Rakhmankulova Z., Choriev Sh., Yusupova D., Muminov O. The Historiography of The Relations Between Central Asian Khanates And Ottoman Empire In The 19th And At The Beginning Of The 2oth Centuries / International Journal of scientific \& technology research volume 9 , issue 02, February 2020 ISSN 2277-8616; Z.Rakhmankulova The National Library Of Uzbekistan As A Digital Humanities Center In Uzbekistan. The American Journal of Social Science and Education Innovations (ISSN - 2689-100x). October 12, 2020. -P. 25-33 Doi: https://doi.org/10.37547/tajssei/Volume 02Issue10-05; Choriev, S. S. (2019). The history of Baltic nation diaspora in Uzbekistan.

ISJTheoretical\&AppliedScience,02(70), 19-25

https://dx.doi.org/10.15863/TAS.2017.12 .56.10. Choriev SS (2017) CLASSIFICATION OF THE Turkestan ASSR documentation in the Central State Archive of the Republic of 
Uzbekistan. ISJ Theoretical \& Applied Science, 12 (56): 50-54. https://dx.doi.org/10.15863/TAS.2019.0 2.70.5; Khayriya Burieva. Toponyms of Tashkent as a factor of reflection of historical processes (1917 - 1980). 3-4. American Journal of Research P. 143-151 (2019).; A. Nazarov (2020) Scientific societies in the Turkestan governorategeneral as an instrument of colonial statehood (archival source study) Journal of Critical Reviews ISSN- 23945125 Vol 7, Issue 7, 2020 http://dx.doi.org/10.31838/jcr.07.07.195

4. Burns A. Travel from India to Kabul, Tatarstan and Persia. Vol. II. -M., 1848. 389-397 p.

5. Valieva D. Foreign economic relations of the Bukhara and Khiva khanates in the first half of the 19th century // Shaqshunoslik (Oriental studies). 1997. No. 8. -S. 165

6. Vambery A. Journey across Central Asia. -SPb., 1865.301-307 p.

7. Bartold V. Report on a business trip in Turkey. In 9 volumes -M.: Science. 1968. Vol.2. P.462

8. Sadie Ali Rais. Mirotul mamolik. -T .: Fan. 1963. -B.160

9. Mehmet Emin Efendi. Istanbuldan Orta Asyaya seyahat.-Ankara. 1986. $113 \mathrm{s.}$

10. Valieva D. Foreign economic relations of the Bukhara and Khiva khanates in the first half of the 19th century // Shaqshunoslik (Oriental studies). 1997. No. 8. -S. 165

11. Mannonov B. From the history of ambassadorial relations // Shaqshunoslik (Oriental studies). 1999. No. 9. Pp.101-119

12. Rakhmankulova, Z. B., \& Rakhmankulova, M. B. (2019). SOME PECULIARITIES OF THE BOOKBINDING
IN TEMURID'S EPOCH. Theoretical \& Applied Science, (10), 266-272.

13. Rahmankulova Z. Ottoman Empire and the political activity of England in Central Asia in the 19 th century. European Society for Central Asian Studies Tenth Conference. Central Asia Sharing Experiences and Prospects. Ankara. 2007.

14. Rahmankulova Z. Rejuvenating silkroad: past present and future of Turkey-Uzbekistan relations. 1 st edition Istanbul Sabahattin Zaim university publications. - Turkey. 2019. - pp. $185-186$

15. Rahmankulova Z. Birinci dunya savasi ve Turkistan. Uluslararasi Asya ve Africa calismalari kongresi. 38. ICANAS (bildiri ozetleri). Ankara. 2007. p.304

16. Rakhmankulova, Z., Choriev, S., Yusupova, D., \& Muminov, O. The Historiography of The Relations Between Central Asian Khanates And Ottoman Empire In The 19 th and At The Beginning Of The 20 th Centuries.

17. Чориев Ш., Рахмонкулова 3. (2016). Материалы личных фондоа ЦГА РУз о деятельности русских востоковедов в Туркестане. “Личность и время. Николай Остроумов: востоковед, просветитель, летописец эпохи" Матер.междунар.научн.конф.

Ташкент, Рp. 67-78

18. Boltabayevich, B. B., \& Shodievna, B. O. (2020). Individual Approach To The Formation of Artistic And Creative Talents Of Students In Art Schools. The American Journal of Social Science and Education Innovations, 2(08), 637-642.

19. Baymetov, B. B., \& Sharipjonov, M. S. O. (2020). Development Of Students' Descriptive Competencies In Pencil Drawing Practice. The American 
The American Journal of Social Science and Education Innovations (ISSN - 2689-100x)

Published: October 21, 2020 | Pages: 89-96

Doi: https://doi.org/10.37547/tajssei/Volumeo2Issue10-14

2020:5. 525

OCLC - 1121105668

Journal of Social Science and Education Innovations, 2(08), 261-267.

20. Rakhmankulova, Z. (2020). The National Library Of Uzbekistan As A Digital Humanities Center In Uzbekistan. The American Journal of Social Science and Education Innovations, 2(10), 25-33. 